\title{
INTERACTION OF EDUCATION, SCIENCE AND BUSINESS IN TERMS OF DIGITAL ECONOMY DEVELOPMENT
}

Vladinir V. Klimuk ${ }^{1}$, Associate professor Ph.D.; Andrejs Lazdins ${ }^{2}$, Assistand professor Dr.oec. ${ }^{1}$ Baranovichi State University; ${ }^{2}$ Latvia University of Life Sciences and Technologies

Abstract. The normative basis for the regulation of effective relationships between the educational, scientific and business sectors is presented. Based on statistical data, the dynamics of the development of the innovation infrastructure in the Republic of Belarus is analyzed and shows the need for change in collaboration between universities and business structures, development it. The university development models "University 3.0" are described which demonstrates the need for university-business collaboration. The indicators of the development of the innovation environment in the Republic of Belarus are analyzed. University cooperation should take place the east as well the west direction. The aim to analyse experience of the collaboration models of education and business in the context of efficiency and quality. Research tasks: to collect information on theoretical aspects on experience of collaboration model; to describe and explain the role and perspective of the model of universitiesbusiness cooperation. Experience, literature and internet source content analysis. Selected data were processed and interpreted applying statistical data processing and interpretation methods as well as matrix structuring, index approach and method of synergy. The goal has been achieved and the tasks are fulfilled.

Key words: sustainable development, digital economy, business incubator, "University 3.0". JEL code: 031.

\section{Introduction}

The effectiveness of the scientific, innovative project is determined by the synergy between the participants, which allows maximizing the planned result, compared with the sole, separate work.

Research goal - to analyse experience of the collaboration models of education and business in the context of efficiency and quality. Research tasks: 1. to collect information on theoretical aspects on experience of collaboration model. 2. to describe and explain the role and perspective of the model of universities-business cooperation. Research methods: for analysis and evaluation methods were used content analysis of literature and internet sources was performed to prepare the research paper. The selected data were processed and interpreted applying statistical data processing and interpretation methods as well as matrix structuring, index approach and synergistic method.

Research innovation: analysis of an innovative collaborative model between universities and business structures.

The effectiveness of the functioning of organizations, considering the growing competition within the country, as well as from abroad, is determined by the conditions and actions taken in the direction of cooperation. By combining certain types of resources of partner organizations, the aim is to strengthen competitive positions and achieve synergies from cooperation, in contrast to the possible result of individual work.

The current stage of development of society is based on innovations in each of the spheres of life and sectors of the economy. The leading role in the socio-economic development of the country based on the intensification of innovation processes should be taken by educational and scientific organizations. The university needs to develop innovative, creative, entrepreneurial initiatives for young people, to form relevant professional competencies. And the main principle in this process is the principle of "the utility of labor" - any ongoing activity should be in demand, useful, otherwise the invested funds are unjustified. The university is gradually transformed into an innovative scientific and educational economic center, which allows to train a highly qualified specialists, create an innovative scientific and technical development, incorporating it into practical areas of the country's economy. 
Researcher Neborsky E.V. based on a compilation of scientific materials, was determined four formats of the university models. Format 1.0 "Corporate University" - the first European universities, organized as corporations of students and teachers, whose external referent was culture. Format 2.0 "Research University" - various forms of university life organization, such as the "Intellectual University" by J. Newman, the "Research University" by V. Humboldt and later the "University of Culture” by H. Ortega i Gasset, united by the idea of "Pure Science” and "Universal Knowledge”. Format 3.0 "Technocratic (innovation) University" - a complex of education, science and business, which is a "Multiversity" K. Kerr control mechanisms similar factory-production. Format 4.0 "Biocomputer University" is a promising model of universities that combine physical and virtual space, developing on digital platforms. As the external factor is creativity thet the educational process is based on meta-individuality and smart technologies (Neborsky, E. V., 2017).

Kuznetsov E. B., Engovatova A. A. in their work, a modern university is defined as „a resource base for ensuring synergy of convergence of types of activity" and presents an assessment of the contribution of universities to the development of the economy, which exceeds the economic effect of individual industries. Scientists also identify 4 models of university development according to their main purpose: educational "University 1.0", educational and research "University 2.0", educational, research and technology transfer function "University 3.0", educational, research, technology transfer and future knowledge provider function „University 4.0" (Kuznetsov E. B., Engovatova A. A., 2016).

Callas M.S. in his study emphasizes the existing problems of "uneven distribution among partners, the pinpoint nature of interaction with enterprises, which lessens effective triangular cooperation" (Callas M. S., 2011).

The issues of interaction of educational, scientific, business organizations are considered in the context of the cluster approach. Anissyna N. N. explains as a structure for stimulating innovation in the university, an innovation cluster is defined, which „... should be viewed as a network of enterprises in the real sector of the economy interrelated in innovation activity and organizations generating new knowledge: universities, research centers, technology transfer structures and business associations" (Anissyna N. N., 2010). Scientists emphasizes the formation of the cluster is on the scientific and educational functions based. A cluster is a network organization of complementary, geographically interrelated relations of cooperation between enterprises and organizations (including specialized suppliers of goods and services, as well as producers and buyers), united around a research and educational center, which is connected by partnership relations with local institutions and authorities to increase competitiveness of enterprises, regions and national economy " (Jaseva G. A., 2008).

One of the main ones in the process of coordinating the functioning of the socio-economic system is the authorities, which must prepare a sTable and operatively adapTable institutional base for the development in the country (region). Some researchers consider interaction as a network of participants using shared resource capabilities to achieve a common goal - the creation of an innovative product (service). In order to improve the efficiency of integration processes in the field of education, science and business, Makoveeva V.V. stressed the need to form network structures with the functions of "interaction, integration and organization of institutions" (Makoveeva V. V., 2011). The advantages of creating a network are the speed of adaptation to changing conditions, the concentration of activities of network participants on their core competencies, the optimisation of production and sales costs, the use of a joint resource base. 
The direction of effective interaction is also reflected in one of the 17 sustainable development goals of the Republic of Belarus "Partnership for Sustainable Development", included in the Sustainable Development Agenda until 2030 (Agenda - 2030). This goal aims to strengthen global partnerships to promote and achieve ambitious goals by providing knowledge, experience, technology and financial resources (Basic Message (summary)..., 2017). Within the goal, several indicators have been identified, the dynamics of which determines the degree of effectiveness of the implementation of the country's sustainable development strategy (Fig. 1).

The rate of changes of index of consumer prices

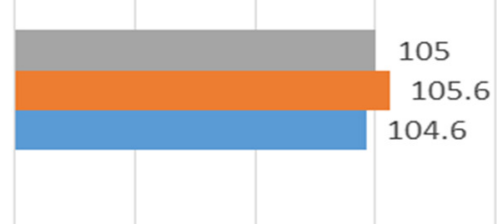

the rate of chnges of godds and services

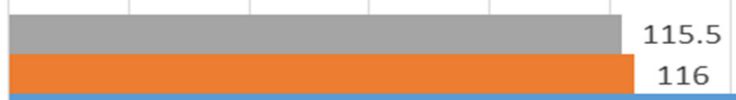

The rate of changes of GDP

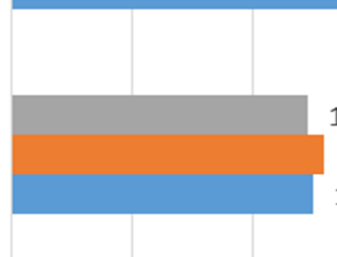

90

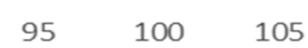

102.3

103

102.5

2020 (forecast) $=2018=2017$

Source: author calculations based on Statistical Yearbook of the Republic of Belarus, 2018

Fig. 1. The rate of change of indicators of the sustainable development goal of the Republic of Belarus „Partnership for Sustainable Development", \%

The top management of countries emphasizes undoubted role of science in the cooperation with the real sector. The President of the Republic of Belarus, Alexander G. Lukashenko, during the 2nd Congress of Scientists of the Republic of Belarus noted the urgent need for interaction between science, education and business, emphasizing the leading role of industry: "After all, industry is the core of all innovations.

There are No countries with strong science and weak industry. And vice versa „... the industry, in conjunction with science and the education system, must solve several main issues dictated by time: to determine the directions of diversification and modernization of production - from the examination of new technologies and equipment to participation in the creation and putting them into operation. New modern plants should be built, based on scientific basis. To ensure systematic work in the field of assessing the reliability and quality of products at all stages - from its design to production" (Lukashenko A G., 2018). The role of science in the development of the modern economy is significantly increasing, which is also expressed in the volume of innovative products produced, the export of high-tech products, and research costs (Fig. 2-3). The country's top leadership defines the scientific component as one of the leading tools in the development of a modern socio-economic system and building a new model - an innovative economy based on the interaction of functional units - education, science and business. 


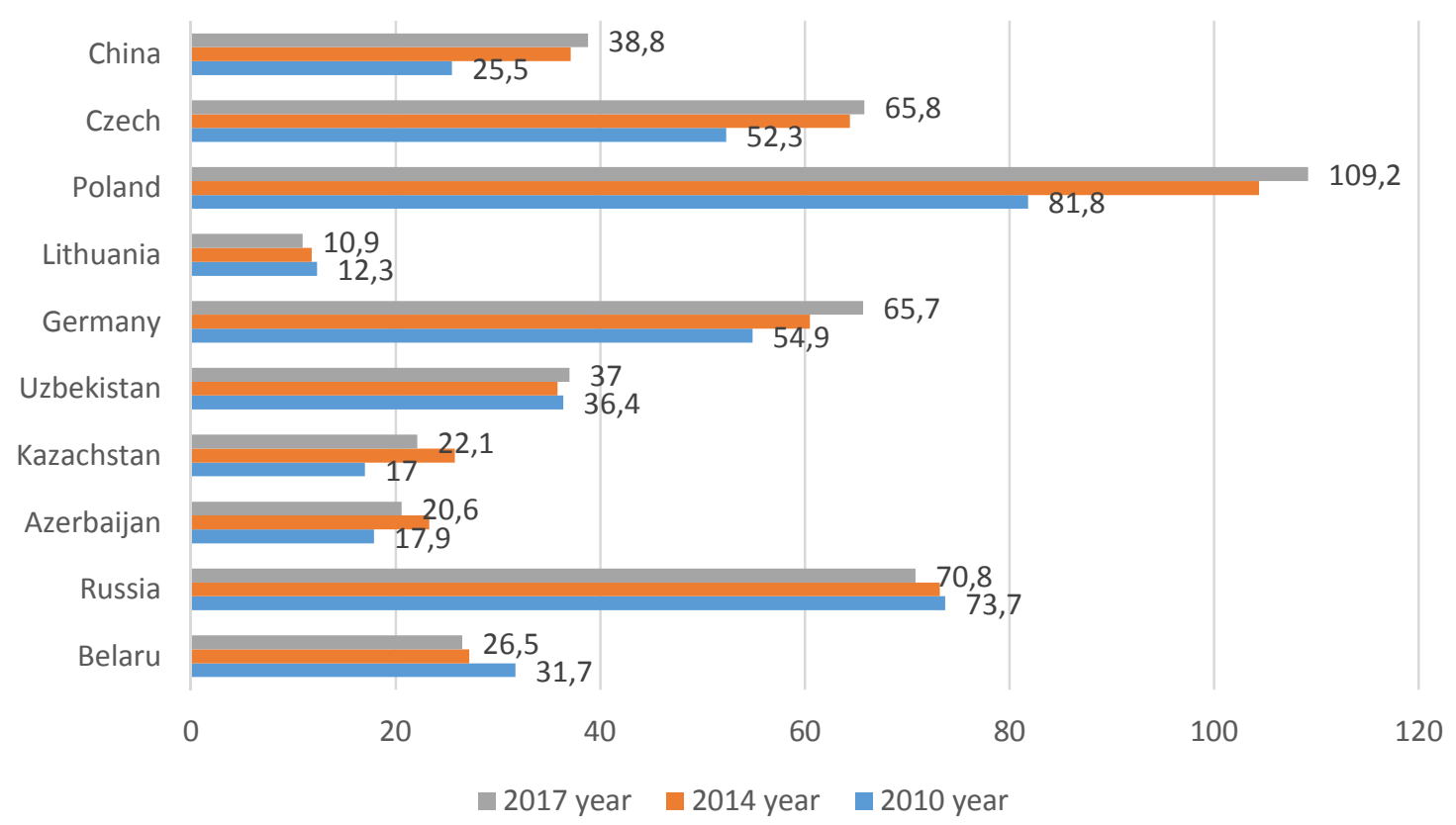

Source: author calculations based on Statistical Yearbook of the Republic of Belarus, 2018

Fig. 2. The number of people employed in research and development, thousand people

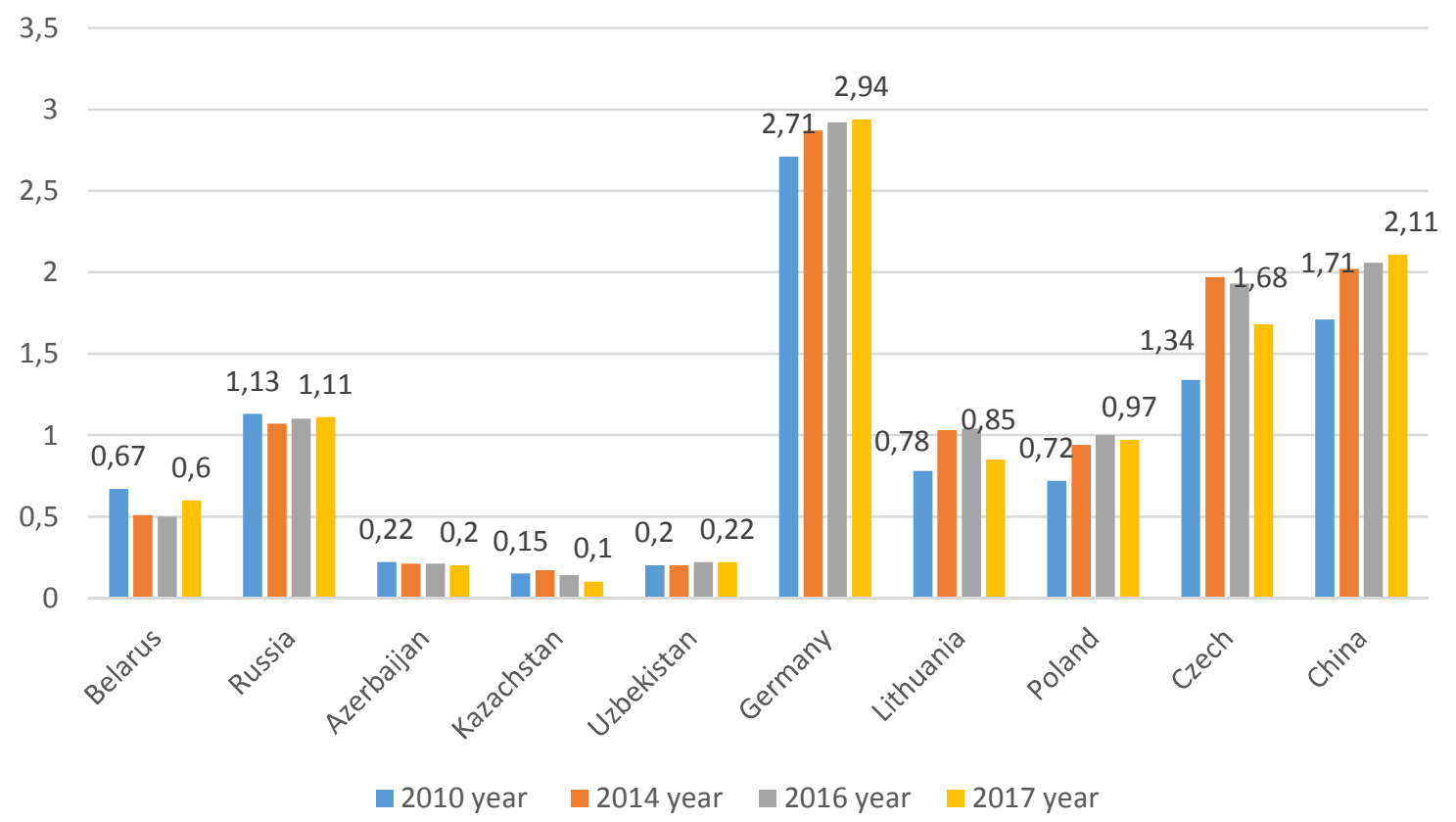

Source: author calculations based on Statistical Yearbook of the Republic of Belarus, 2018

Fig. 3. Domestic expenditures on research and development in the country, in \% of GDP

\section{Research results and discussion}

At the meeting of the Council on Science and Education on the issues of global competitiveness of Russian science, the President of the Russian Federation Vladimir V. Putin noted that "the interaction of science and business should be a key condition for the implementation of the program „Digital Economy".

Vladimir Putin stressed the need to develop own research infrastructure in the country, emphasized the need to form powerful international research groups in Russia, to develop scientific cooperation with other countries and to increase the openness of native science, to expand interaction with other countries in science and to form powerful international research centers in the country (Putin V., 2018). 
The current research was conducted by the experts of the School of Law and Diplomacy named after Fletcher at Tufts University in collaboration with Mastercard to assess the development of the digital economy in a country context (Fig. 4).

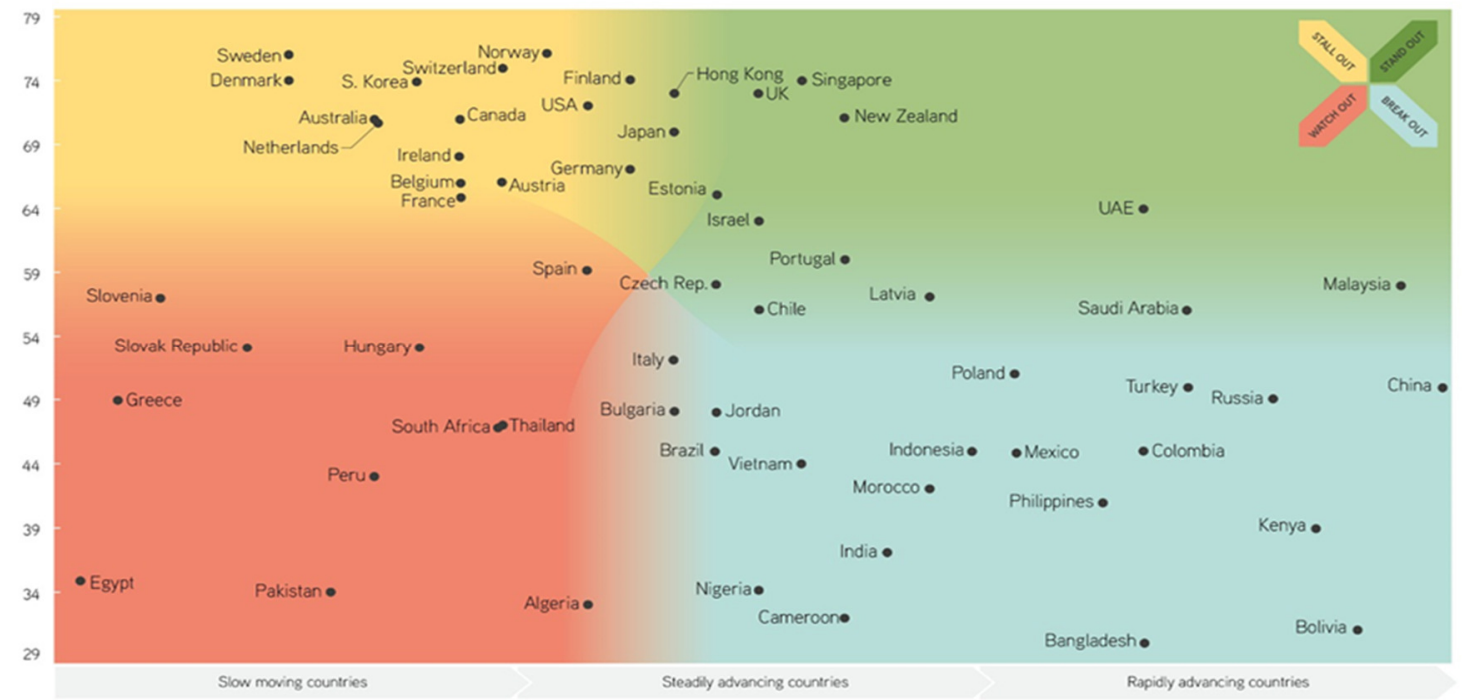

Source: author calculations on 60 Countries' Digital Competitiveness, Indexed

Fig. 4. Evaluation of the development of digital economy in a country context

Russia is in a promising group of countries, characterized by the intensifying (based on 20082015 data) of a general level of „digitalization”, a transitional stage to a group of leading countries (Norway, Sweden, Switzerland, Denmark, Finland, Singapore, South Korea, the United Kingdom, Hong Kong, USA).

The creation of new, informational productions that meet the demands of society and enable them to participate in the global competitive struggle forces industry organizations to cooperate (60 Countries' Digital Competitiveness, Indexed, 2017).

Often there is No direct, not formal, interaction, although everyone has an interest in the success of the project. Some participants of the process adhere to the position of receiving returns only at one stage, without considering the need for productive completion of the whole complex of operations: from the generation of an idea to its mass use in practical areas.

The origin of an idea is, as a rule, not a spontaneous decision, but a form of expression of an urgent need (The most digital countries in the world, 2017).

The emerged idea of improving an area, the components of which is updated by a detailed analysis of market conditions in order to assess the level of demand, the potential supply of the idea's originality, its scale and, directly, the social and economic benefits of implementation (Klimuk, V. V., Semashko M. Y., 2018).

The conducted analysis of the economic basis, confirmed by the organizational and technical analysis of profitability, allows us to create an innovative development. It is important to consider not only own resources, but necessarily the potential cooperation (intellectual, material and technical, financial).

The resulting sample (prototype) of innovation must necessarily pass the test sale stage in order to get feedback from customers.

The success of the previous stage is well-grounded decision of mass production with components of innovation promotion for the real sector of the economy, ensuring satisfaction of needs and improving the quality of life of the population, the level of scientific and technological development of organizations, regions, and the country. As a result, the integrated structure (educational, 
scientific, business sectors) forms a synergetic effect that differs from the total result of separate work of each component of the system. However, a synergistic effect is possible only if the condition of innovative product or service is observed.

Growth in the share of innovative products indicates an effective state policy of industrialization, modernization of industrial production, the cost of research and development (Fig. 5).

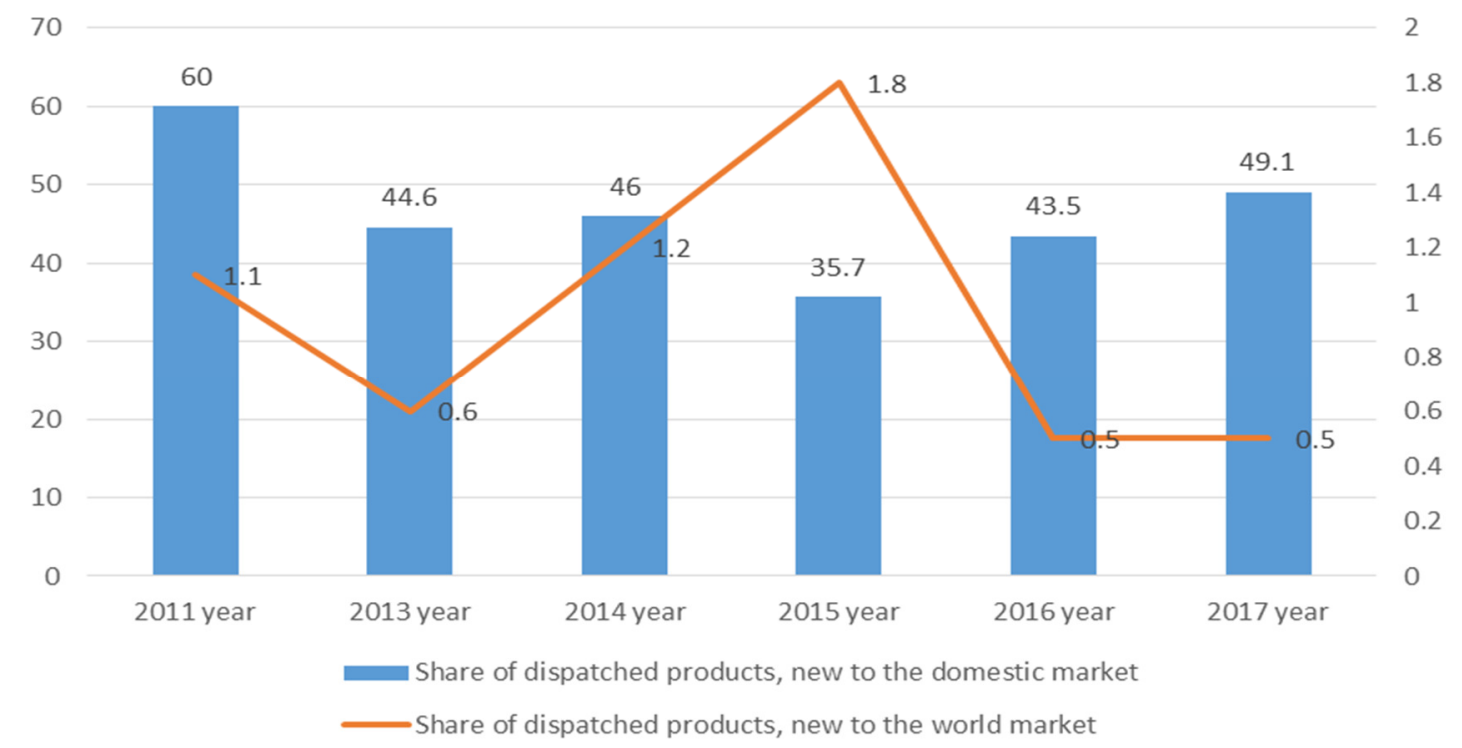

Source: author calculations based on Statistical Yearbook of the Republic of Belarus, 2018

Fig. 5. The share of dispatched industrial products, new to the domestic market and new to the world market, respectively \%

The presented algorithm for implementing an innovative solution must be accompanied using mechanisms for effective interaction. One of them is the model of business-incubation. The goal of business incubator is the creation, testing and market access for new firm producing goods (as a rule the original one). Customers focus on the current market on innovative products; therefore, the business incubator must meet this criterion. This model corresponds to the implementation of the concept of "University 3.0" - a modern entrepreneurial university based on the integration of the educational, scientific and business environment.

There are 4 formats of the university model, formed at different historical stages. Format 1.0 "Corporate University" - the first European universities, organized as corporations of students and teachers, whose external referent was culture. Format 2.0 "Research University" - various forms of university life organization, such as the "Intellectual University” by J. Newman, the "Research University" by V. Humboldt and later the "University of Culture” by H. Ortega -Gasset, united by the idea of „pure science "and" universal knowledge. Their external referent was the truth. Format 3.0 "technocratic (innovative) university" is a complex set of education, science and business, which is K. Kerr's "multiversity" with control mechanisms like factories-manufactures. The external referent is quality, and the university is increasingly immersed in bureaucracy and accountability. Format 4.0 "Biodigital University" is a promising model of universities that combine physical and virtual space, developing on digital platforms. The external referent is creativity, when the educational process is based on meta-individuality and smart technologies (Neborsky, E. V., 2017).

Thus, an effective cooperation model for achieving mutual economic effect should be formed based on an educational, scientific, business component with the obligatory participation of the authorities in coordinating and managing the relationship processes. The author suggests an interaction model with a description of the activities of each component and the results of their successful implementation (Fig. 6). 


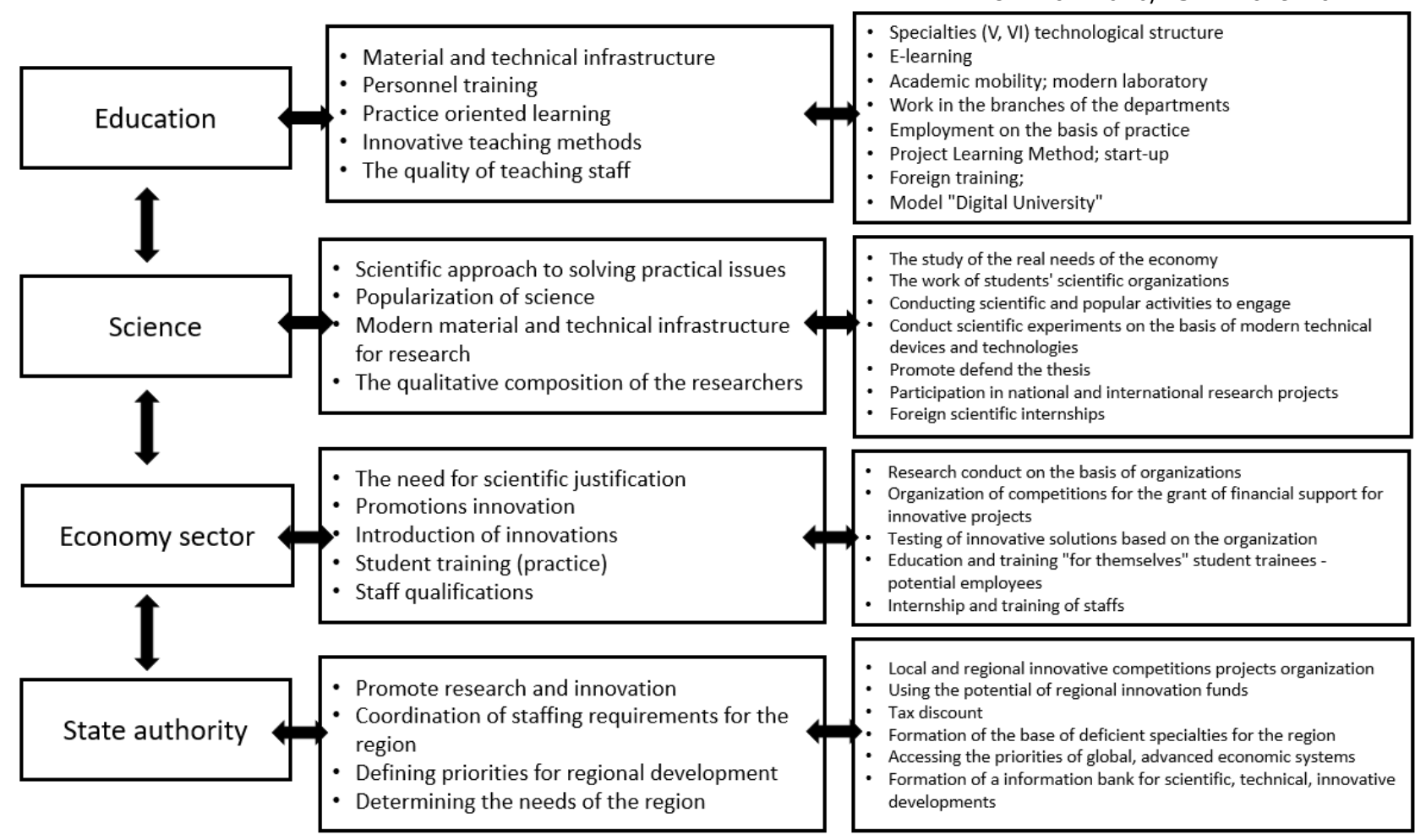

Source: the authors developed a model

Fig. 6. A four-force model for cooperation in education, science, economics and State authority

\section{Conclusions, proposals, recommendations}

1) The Innovation development of the country are insufficient of the lack of cooperation between universities and real economy. Universities prepare specialists which are not requested from employers which not specialties with specific knowledge.

2) Synergistic effect is possible only in the case of direct interaction between the sectors of education, science and business, which is expressed in the creation of a market demand, competitive with world manufacturers, unique, as a rule, high-tech goods.

3) As an effective model for the development of cooperation between educational institutions, scientific organizations, and business structures, a model of an innovative, entrepreneurial university called "University 3.0" has been defined. Considering the experience and evaluation of strategic plans, we consider reasonable the transition to building a model of "University 4.0" based on the development of digital technologies in the implemented activities of the university (educational activities, scientific activities, international cooperation, entrepreneurial initiatives).

4) The development of this model "University 3.0" should be the transformation into an innovative, scientific, industrial and technological, what can be entrepreneurial cluster forming process of satisfying all requests at each stage and in each component of the interconnected chain. The creation of such a cluster seems appropriate for differentiation by specialization (engineering, medical, educational, etc.) and regionalization.

5) Interdisciplinary research should be the priority type of scientific, innovative activity of universities ensuring an increase in the efficiency of functioning of the object under study through the cooperation of specific intellectual specialists (knowledge of professionals) and the resource bases - enterprise (conducting experiments on modern, powerful equipment of other organizations).

6) The growth in expenditures on research and development, the number of scientific personnel engaged in research indicates an increase in the indicators of innovative activity of the country, an increase in the rating of its positions in the global innovation index. 


\section{Bibliography}

1. Anissyna, N. N. (2010). Innovaci nauko-obrazovatelni klaster kak sposob organizacii innovacionni dejatelnosti $\vee$ VUZe/Kreativnaja ekonomika (Innovative research and education cluster as a way of organizing innovation activities at the university/creative economy). No. 4. 2010. Retrieved: https://creativeconomy.ru/lib/4133. Access: 30.01.2019.

2. 60 Countries' Digital Competitiveness Indexed (2017). Retrieved: https://hbr.org/2017/07/60-countriesdigital-competitiveness-indexed. Access: 30.01.2019.

3. Kallas, M.S. (2011). Vzaimodeistvie nauki, obrarozovanija i biznesa kak osnova formirovanija innovacii sredi $v$ Rossii (The interaction of science, education and business as the basis for the formation of the innovation environment in Russia). Вестник Томского государственного университета. Serija: „Ekonomika i pravo” 2011; No. 4, (16). p. 186-191.

4. Klimuk, V. V., Semashko, M. Y. (2018). Innovatization of industrial business in the direction of integration with education and science/Economic trends. Retrieved: http://ej.barsu.by/download/1//3_7.pdf. Access: 28.02.2019.

5. Kuznetsov, E. B., Engovatova, A. A. (2016). "Universiteti 4.0": tocki rosta ekonomiki znanii $\vee$ Rossii ("Universities 4.0": points of growth of the knowledge economy in Russia). Innovacii 2016; No. 5, (211). p. 3-9.

6. Jaseva, G. A. (2008). Klasternaja koncepcija innovacionnovo razvitija ekonomiki: obosnovanie i mehanizm realizaciji (Cluster concept of innovative development of the economy: the rationale and mechanism for implementation). Vestnik RUDN. Serija: „Ekonomika” 2008; No. 4, p. 63-67.

7. Makoveeva, V. V. (2011). Setevoe vzaimodeistvie - kluceboi faktor razvitija integracii obrazovanija (Networking is a key factor in the development of education integration). Nauka i biznesa 2011; p. 163-166.

8. Neborsky, E. V., (2017). Rekonstruirovanie modeli universiteta: perehod na formu 4.0 (Reconstruction of the university model: transition to the 4.0 format). Retrieved: https://mir-nauki.com/PDF/26PDMN417.pdf. Access: 28.02.2019.

9. Samie cifrovie straini mira (The most digital countries in the world) (2017). Retrieved: https://hbrrussia.ru/innovatsii/trendy/p23271. Access:30.01.2019.

10. Lukashenko, A G. (2018). The first direction of development of science - in conjunction with the production. Retrieved: https://www.sb.by/articles/lukashenko-pervoe-napravlenie-razvitiya-nauki-v-soedinenii-sproizvodstvom.html. Access: 30.01.2019.

11. Osnovnie soobscenie (rezume) dobrovolnogo nacionalnogo doklada Respubliki Belarus ob osuscestvlenii novestki dna v oblasti ustoiciviva razvitija na period do 2030 goda (THE MAIN MESSAGE (SUMMARY) OF THE VOLUNTARY NATIONAL REPORT OF THE REPUBLIC OF BELARUS ON THE IMPLEMENTATION OF THE AGENDA FOR SUSTAINABLE DEVELOPMENT FOR THE PERIOD UP TO 2030). (2017). Retrieved: https://sustainabledevelopment.un.org/memberstates/belarus. Access: 02.02.2019.

12. Putin, V. V., (2018). Putin zajavil o neobhodimosti nacelitsja na prorivnie proekti v nauke (Announced the need to target breakthrough projects in science). Retrieved: https://tass.ru/nauka/4940938. Access: 30.01.2019.

13. Statistical Yearbook of the Republic of Belarus, 2018 (2018). Retrieved: http://www.belstat.gov.by/en/ofitsialnaya-statistika/publications/statistical-publications-data-booksbulletins/public_compilation/index_12543/ Access: 30.01.2019. 